\title{
MODEL MENTAL SISWA KELAS X SMA LABORATORIUM UNDIKSHA SINGARAJA TENTANG IKATAN ION DAN IKATAN KOVALEN
}

\author{
Ni Luh Yuni Ari Pratiwi ${ }^{1}$, I Wayan Suja ${ }^{2}$, I Nyoman Selamat ${ }^{3}$ \\ Universitas Pendidikan Ganesha \\ Singaraja, Indonesia \\ e-mail: pratiwi.luh, wayan.suja, nyoman.selamat, @undiksha.ac.id
}

\begin{abstract}
Abstrak
Penelitian ini bertujuan untuk mendeskripsikan dan menjelaskan profil model mental siswa, serta menganalisis faktor-faktor yang memengaruhi terbentuknya model mental alternatif siswa kelas X MIA di SMA Laboratorium Undiksha Singaraja pada materi ikatan ion dan ikatan kovalen. Penelitian ini menggunakan pendekatan mix methods, jenis sekuensial. Pengumpulan data dilakukan dengan observasi, tes model mental, dan wawancara. Instrumen yang digunakan adalah tes diagnostik pilihan ganda dua tingkat dan wawancara dengan pertanyaan menyelidik. Hasil penelitian menunjukkan persentase siswa yang memiliki model mental ilmiah tentang ikatan ion dan kovalen sebanyak $53,33 \%$ model mental alternatif sebanyak $38,89 \%$, dan $7,78 \%$ tidak memberikan tanggapan. Faktor-faktor yang memengaruhi terbentuknya model mental alternatif meliputi kekurangan informasi, kekeliruan penalaran, dan buku teks kimia yang digunakan siswa sebagai sarana belajar. Sehubungan dengan temuan tersebut, guru kimia di SMA perlu menerapkan strategi pembelajaran yang tepat untuk mengajarkan ketiga level kimia secara utuh.
\end{abstract}

Kata kunci: ikatan ion, ikatan kovalen, model mental, model mental alternatif

\begin{abstract}
This research was aimed to describe and explain the profile of mental model student's, and analyze the factors that influence the formation of alternative mental models of class X MIA students at SMA Laboratorium Undiksha Singaraja about ionic bonding and covalent bonds material. This research is a mix method approaches in research, a sequential type. Data collection is done by observation, mental model tests, and interviews. The instrument used in this study was a diagnostic test two tier and interview with probing questions. The results showed the percentage of students who experienced a scientific mental model of ion bonds and covalent bonds of $53.33 \%$ of students, had an alternative mental model of $38.89 \%$, and as many as $7.78 \%$ did not have a mental model. Factors that influence the formation of alternative mental models include lack of information, errors of reasoning, and chemical textbooks that students used. Related with that research, chemistry teachers in high schools need
\end{abstract}


to apply appropriate learning strategies in the process of learning chemistry.

Keywords: ionic bonding, covalent bonding, mental model, mental model alternative

\section{PENDAHULUAN}

Pada dasarnya, pembelajaran konsep-konsep kimia perlu melibatkan pengkajian level makroskopis, submikroskopis dan simbolik. Salah satu bahan kajian kimia yang menuntut pemahaman interkoneksi tiga level kimia adalah ikatan kimia, yang didalamnya mencakup ikatan ion dan ikatan kovalen. Kemampuan untuk memahami proses pembentukan ikatan ion dan ikatan kovalen merupakan kompetensi inti dalam pembelajaran kimia. Namun, berbagai hasil penelitian menunjukkan bahwa sebagian besar siswa harus berusaha keras agar memahaminya. Kesulitan siswa dalam belajar kimia salah satunya terletak pada pemahaman level submikroskopis untuk menjelaskan fenomena makroskopis dan penggunaan simbolsimbol kimia. Ketidakmampuan siswa membangun interkoneksi di antara ketiga level kimia tersebut memunculkan pandangan bahwa kimia merupakan pelajaran sulit, membosankan, bahkan menakutkan bagi beberapa orang siswa (Suja \& Retug, 2013a). Model mental dapat didefinisikan sebagai representasi intrinsik yang bersifat personal dalam pikiran pebelajar tentang objek, ide, atau proses yang akan digunakan untuk menjelaskan atau memprediksi sebuah fenomena (Wang, 2007). Berdasarkan pendapat Sendur et al. (2010) dan pakar lainnya, model mental dalam penelitian ini antara lain tidak ada jawaban/tanggapan (No Respons/NR), miskonsepsi khusus pada hal tertentu (Specific Misconcoptions/SM), benar sebagian (Partially Correct/PC), dan benar secara keilmuwan (Scientifically Correct/SC). Berbagai penelitian telah dilakukan untuk mengetahui model.

Mental siswa. Temuan penelitian Suja (2015) menunjukkan bahwa tidak hanya di SMA, tidak utuhnya interkoneksi ketiga level kimia juga terjadi di Perguruan Tinggi. Ketidakutuhan model mental pebelajar di Perguruan Tinggi kemungkinan terbawa dari kebiasaan belajar di SMA. SMA Laboratorium Undiksha Singaraja merupakan sekolah swasta favorit di Kota Singaraja. Sebagai sekolah favorit, sudah selayaknya SMA Laboratorium Undiksha Singaraja memiliki input dan output yang baik. Akan tetapi, hasil observasi dan wawancara yang dilakukan menunjukkan bahwa proses pembelajaran kimia di kelas masih didominasi level makroskopis langsung ke level simbolik, dan masih banyak siswa yang mengalami kesulitan dalam belajar kimia terutama pada pemahaman level submikroskopis untuk menjelaskan fenomena makroskopis dan penggunaan simbol-simbol kimia. Selain itu, hasil penelitian Riyastini (2015) menunjukkan bahwa siswa kelas XI dan XII IA di SMA Laboratorium Undiksha Singaraja mengalami miskonsepsi pada konsepkonsep yang membutuhkan pemahaman level submikroskopis dan sebesar $61,05 \%$ siswa tergolong memiliki pemahaman kimia yang rendah pada topik stoikiometri. Hal tersebut mengungkapkan kurangnya pemahaman siswa terkait ketiga level kimia beserta interkoneksinya. Sejalan dengan hal tersebut, temuan penelitian Sucitra (2016) menunjukkan profil model mental siswa kelas XI SMA Laboratorium Undiksha Singaraja tentang korelasi struktur molekul terhadap sifat senyawa organik. Hasil penelitiannya meliputi 1,35\% model mental ilmiah (Scientifically Correct, SC) serta

$98,65 \%$ model mental alternatif, yang terdiri atas 5,53\% model mental tipe NR (No Response), 42,57\% tipe SM (Specific Misconceptions), dan 50,54\% tipe PC (Partially Correct), dengan rerata skor sebesar 21,47 dari skala 100 . Berdasarkan pemaparan di atas, perlu dikaji lebih dalam lagi terkait model mental siswa. Oleh karena itu peneliti terinspirasi untuk melakukan penelitian dengan judul "Model Mental Siswa Kelas X SMA Laboratorium Undiksha Singaraja tentang Ikatan Ion dan Ikatan Kovalen". Penelitian ini dilaksanakan di SMA Laboratorium Undiksha Singaraja pada semester ganjil tahun ajaran 2018/2019. Hasil penelitian ini diharapkan dapat memberikan gambaran model mental siswa dan faktor-faktor yang menyebabkan terbentuknya model mental alternatif terkait ikatan ion dan ikatan kovalen.

Hasil tes dalam bentuk skor jawaban siswa terhadap tes model mental disajikan dalam bentuk tabel yang berisi no urut, kode siswa, dan skor siswa. Penyajian data hasil tes model mental siswa dapat dilihat pada Lampiran 06. Pelaksanaan tes model mental dilakukan di SMA

\section{METODE}

Penelitian ini menggunakan pendekatana mixed methods dan jenis sequential. Penelitian dilaksanakan di SMA Laboratorium Undiksha Singaraja pada bulan November 2018-januari 2019. Data yang diperoleh dikumpulkan melalui metode observasi, pemberian tes model mental, dan wawancara. Instrument yang digunkana adalah tes model mental dan pedoman wawancara. 
Teknik analisis dilakukan secara deskriptif, yang melibatkan hubungan antara jawaban siswa dan argumentasinya dengan melibatkan tiga level kimia. Wawancara melibatkan reduksi data, penyajian data, dan penarikan kesimpulan. Data pada penelitian ini berupa hasil belajar tes model mental dan factor-faktor penyebab terbentuknya model mental alternatif. Laboratorium Undiksha Singaraja dengan melibatkan 45 siswa kelas X MIA yang tersebar di dua kelas, yaitu kelas X MIA 1 dan X MIA 2. Data profil model mental siswa berdasarkan persentase masing-masing kategori disajikan dalam bentuk diagram pie pada Gambar 1.

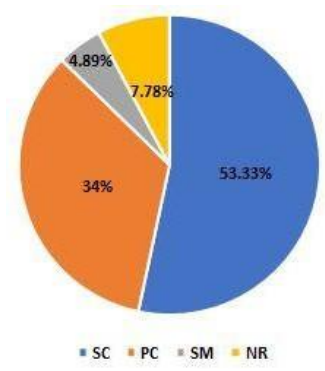

Gambar 1. Diagram Pie rofil Model Mental Siswa

Diagram pie profil model mental siswa pada Gambar 4.1 menunjukkan bahwa 53,33\% konsepkonsep ikatan ion dan ikatan kovalen dipahami oleh siswa kelas X MIA SMA Laboratorium Undiksha Singaraja dalam bentuk model mental ilmiah tentang ikatan ion dan ikatan kovalen, sebanyak $38,89 \%$ dalam bentuk model mental alternatif, dan sebanyak $7,78 \%$ tidak ada respons dari siswa. Model mental alternatif tersebut terdiri atas 34\% model mental benar sebagian dan $4,89 \%$ model mental miskonsepsi khusus. Temuan penelitian ini menunjukkan bahwa sebagian besar siswa memiliki pemahaman yang benar terkait interkoneksi tiga level kimia tentang bahan kajian ikatan ion dan ikatan kovalen. Berkaitan dengan indikator yang pertama (soal no 1), sebanyak $97,78 \%$ siswa menjawab bahwa Ne bersifat stabil. Pada level submikrroskipos, siswa mampu menjelaskan bahwa Ne bersifat stabil karena termasuk ke dalam golongan gas mulia dan jumlah elektron valensinya memenuhi aturan oktet. Pada level simbolik, siswa sudah mampu menggambarkan struktur Lewis unsur Ne. Data tersebut menunjukkan siswa mampu menjelaskan kecenderungan unsur untuk mencapai kestabilan sehingga model mental tentang kestabilan unsur tergolong lengkap (model mental ilmiah)

Pada indikator kedua (soal no 2), sebanyak $75,56 \%$ siswa menjawab bahwa senyawa $A B$ tergolong senyawa ionik yang berwujud padat. Pada level submikroskopis, siswa mampu menjelaskan bahwa pembentukan senyawa tersebut melibatkan pelepasan $1 \mathrm{e}$ - dari atom $\mathrm{A}$ menjadi $A_{+}$, selanjutnya elektron tersebut ditangkap oleh atom B menjadi B-. Senyawa ionik memiliki struktur yang sangat rapat karena gaya tarik-menarik antar ion yang bermuatan berlawanan sangat kuat. Siswa lainnya, sebanyak $13,33 \%$ hanya mampu menjawab pada level simbolik, namun tidak mampu menjawab pada level submikroskopis. Sedangkan, sebanyak $11,11 \%$ siwa tidak menjawab soal ini. Pada indikator yang ketiga (soal no 3 ), sebanyak $80 \%$ siswa menjawab Ar termasuk ke dalam golongan gas mulia. Siswa menjelaskan, bahwa Ar memilki jumlah elektron valensi yang sudah memenuhi aturan oktet, sehingga tidak mampu berikatan dengan atom lain (bersifat stabil). Pilihan lainnya, sebanyak $17,78 \%$ siswa hanya mampu menjawab pada level simbolik, sedangkan pada level submikroskopis siswa belum mampu menjelaskannya. Pada indikator keempat (soal no 4), sebanyak $40 \%$ siswa menjawab $\mathrm{NaH}$ tergolong senyawa ionik yang berwujud padat. Siswa menjelaskan bahwa $\mathrm{NaH}$ terdiri atas atom $\mathrm{Na}$ dan atom $\mathrm{H}$. Untuk memenuhi aturan duplet/oktet, atom $\mathrm{Na}$ harus melepaskan $1 \mathrm{e}$ - dan atom $\mathrm{H}$ menangkap 1 e- sehingga tercapai konfigurasi elektron yang stabil. Gaya tarik elektrostatik antara ion-ion yang bermuatan berlawanan menyebabkan senyawa $\mathrm{NaH}$ berwujud padat dan mampu menggambarkan proses pembentukan ikatan senyawa tersebut. Pilihan lainnya, sebanyak $57,78 \%$ siswa mampu menggambarkan proses pembentukan ikatan senyawa $\mathrm{NaH}$, namun belum mampu menjelaskan penyebab senyawa $\mathrm{NaH}$ berwujud padat.

Pada indikator keempat (soal no 5), sebanyak 46,67\% siswa menjawab bahwa sifat fisika yang relevan dengan kristal ionik adalah keras, tetapi rapuh. Siswa menjelaskan bahwa kristal ion bersifat keras karena ion-ion dikelilingi oleh ion-ion yang berlawanan. Jika salah satu kisi kristalnya digeser, maka terjadi tolak-menolak antar ion-ion yang sama. Pilihan lainnya, sebanyak $51,11 \%$ siswa hanya mampu menjelaskan penyebab kristal ionik bersifat keras, namun belum mampu menjelaskan penyebab kristal ionik bersifat rapuh dan belum mampu menggambarkan struktur ion-ionnya. Sedangkan, sebanyak 2,22\% siswa tidak menjawab soal ini. 
Pada indikator keempat (soal no 6), sebanyak 42,22\% siswa menjawab bahwa jenis ikatan antara $\mathrm{Na}$ dan $\mathrm{F}$ dalam senyawa $\mathrm{NaF}$ adalah ikatan ion dan memiliki titik leleh yang tinggi. Siswa mampu menjelaskan bahwa senyawa NaF tergolong senyawa ion karena untuk mencapai kestabilan atom $\mathrm{Na}$ harus melepaskan satu elektron valensinya, sedangkan atom $\mathrm{F}$ harus menangkap satu elektron. Yang menyebabkan titik lelehnya tinggi adalah wujudnya yang padat (ikatan antar ion-ion yang kuat). Pilihan lainnya, sebanyak $48,89 \%$ siswa belum mampu menjelaskan penyebab senyawa NaF memiliki titik leleh yang tinggi. Sedangkan, sebanyak $8,89 \%$ siswa tidak menjawab soal ini.

Pada indikator keempat (soal no 8), sebanyak 33,33\% siswa menjawab bahwa yang merupakan senyawa ionik adalah padatan $\mathrm{CaCl} 2$ dan mampu menjelaskan pada level submikroskopis menggunakan bahasa verbal dan simbolik. Sebanyak $44,45 \%$ siswa menjawab bahwa yang merupakan senyawa ionik adalah padatan $\mathrm{CaCl} 2$ namun tidak mampu mejelaskan pada level submikroskopis. Selain itu, sebanyak $22,22 \%$ siswa tidak menjawab soal ini.

Pada indikator kelima (soal no 7), sebanyak 42,22\% siswa menjawab bahwa jenis ikatan kimia antar atom dalam molekul senyawa HCN adalah ikatan kovalen tunggal dan ikatan kovalen rangkap tiga. Siswa mampu menjelaskan bahwa atom $\mathrm{C}$ akan membentuk satu ikatan kovalen tunggal dengam atom $\mathrm{H}$ dan ikatan kovalen rangkap tiga dengan atom $\mathrm{N}$. Di dalam air, senyawa tersebut terionisasi menghasilkan ion $\mathrm{H}+$ dan $\mathrm{CN}$ - Pilihan lainnya, sebanyak 48,89\% siswa hanya mampu menjelaskan jenis ikatan yang terjadi, namun belum mampu menjelaskan dan menggambarkan reaksi ionisasinya dalam air, serta mengalami kesulitan saat mengambarkan proses pembentukan ikatan antar atom dalam molekul senyawa HCN. Pada indikator kelima (soal no 9), sebanyak $57,78 \%$ siswa menjawab bahwa senyawa yang lebih bersifat kovalen adalah silikon klorida yang berwujud cair. Siswa menjelaskan bahwa silikon klorida lebih bersifat kovalen karena memiliki beda keelektronegatifan yang lebih kecil dari pada senyawa boron trifluorida. Senyawa tersebut bersifaat cair karena gaya tarik-menarik antar molekul lebih lemah. Pilihan lainnya, sebanyak $33,33 \%$ siswa mengalami kesulitan dalam menjelaskan level submikroskopis dan menggambarkan struktur Lewis senyawa silikon klorida.

Pada indikator kelima (soal no 10), sebanyak $17,78 \%$ siswa menjawab bahwa jenis ikatan antar atom dalam molekul $\mathrm{HCl}$ adalah ikatan kovalen. Siswa menjelaskan bahwa $\mathrm{HCl}$ digolongkan ke dalam ikatan kovalen karena penggunaan pasangan elektron secara bersamasama. Siswa lainnya sebanyak $73,33 \%$ mengalami kesulitan dalam menjelaskan pada level submikroskopis. Sedangkan sebanyak $8,89 \%$ siswa tidak menjawab soal ini.

Hasil wawancara siswa dan guru diperoleh faktor-faktor penyebab model mental alternatif, meliputi factor eksternal yaitu buku teks kimia yang digunakan oleh guru dan siswa. Faktor internal rendahnya pemahaman siswa terhadap materi ikatan ion dan ikatan kovalen dan ketidakpahaman siswa tentang level submikroskopis kimia.

\section{HASIL DAN PEMBAHASAN}

Pada indikator pertama, tentang kecenderungan unsur untuk mencapai kestabilannya, distribusi model mental ilmiah tergolong tinggi. Kondisi ini terbentuk dari sebagian besar siswa mampu menginterpretasikan ketiga level kimia. Secara keilmuwan, dalam menjelaskan kecenderungan unsur $\mathrm{Ne}$, terlebih dahulu siswa harus menentukan konfigurasi elektron. Setelah itu, siswa dapat menentukan golongan dan periodenya dalam sistem periode unsur. Kemudian, siswa dapat menggambarkan struktur Lewisnya. Pada indikator kedua, tentang kompetensi siswa untuk membedakan sifat senyawa ionik dan senyawa molekuer, distribusi model mental ilmiah menyumbangkan persentase tertinggi. Kondisi ini terbentuk dari sebagian besar siswa mampu menginterpretasikan ketiga level kimia. Secara keilmuwan, dalam menjelaskan ikatan ion, terlebih dahulu siswa harus mampu menuliskan konfigurasi electron atomatom penyusunnya. Setelah itu, siswa dapat menggambarkan proses pembentukan ikatan ion. Pada indikator yang ketiga, kompetensi siswa dalam menggambarkan susunan elektron valensi atom gas mulia dan atom unsur-unsur lainnya, distribusi model mental ilmiah menyumbangkan persentase tertinggi. Kondisi ini terbentuk dari sebagian besar siswa mampu menginterpretasikan ketiga level kimia. Secara keilmuwan, dalam menggambarkan susunan elektron valensi atom argon, terlebih dahulu siswa harus menentukan konfigurasi elektron terlebih dahulu. Setelah itu, siswa dapat menggambarkan struktur Lewisnya. Pada indikator yang keempat, tentang kompetensi siswa untuk menjelaskan proses terbetuknya ikatan ion beserta contoh senyawanya, distribusi model mental benar sebagian menyumbangkan presentase tertinggi. Kondisi itu disebabkan oleh kelemahan siswa dalam menjelaskan level submikroskopis. Pada level submikroskopis hanya beberapa siswa dapat menjelaskan. Secara keilmuan pada level submikroskopis sifat kristal ionik bersifat keras karena 
ion-ion dikelilingi ion-ion lain yang bermuatan berlawanan. Jika kisi kristalnya digeser, maka akan terjadi tolak-menolak antar ion-ion yang sama (bermuatan sama). Hal inilah yang menyebabkan kristal ionik bersifat rapuh. Temuan ini sejalan dengan hasil penelitian Riyastini (2015) yang menunjukkan bahwa siswa kelas XI dan XII mengalami miskonsepsi pada konsep-konsep yang membutuhkan kajian level submikroskopis dan sebesar 61,05\% pemahaman siswa tergolong rendah pada topik stoikiometri. Temuan ini juga sejalan dengan hasil penelitian Kunde et al. (2018) yang menunjukkan, bahwa profil model mental siswa pada bahan kajian stokiometri tergolong rendah. Pada indikator kelima, tentang kompetensi siswa dalam menjelaskan proses terbentuknya ikatan kovalen tunggal, kovalen rangkap dua, dan kovalen rangkap tiga, distribusi model mental benar sebagian tergolong paling tinggi, presentase tertinggi pada model mental benar sebagian disebabkan oleh kelemahan siswa

Dalam menjelaskan level submikroskopis dan level simbolik. Secara keilmuan, silikon klorida merupakan senyawa yang lebih bersifat kovalen karena memiliki beda keelektronegatifan yang lebih kecil dari pada senyawa boron trifluorida. Senyawa tersebut berwujud cair karena gaya tarikmenarik antarmolekulnya lebih lemah. Temuan ini sejalan dengan hasil penelitian Halim et al. (2012) yang menyimpulkan bahwa siswa mengalami kesulitan ketika menggambarkan senyawa kimia dalam tiga representasi kimia (makroskopis, submikroskopis dan tingkat simbolik). Dari hasil wawancara diperoleh ada beberapa faktor yang menyebabkan terbentuknya model mental alternatif pada materi ikatan ion dan ikatan kovalen. Faktor penyebabnya yaitu faktor eksternal dan faktor internal. Faktor eksternal merupakan faktor yang berasal dari luar diri siswa, yaitu buku-buku teks kimia. Dari hasil observasi, buku pegangan yang digunakan oleh siswa dan guru adalah buku teks (paket). Pada buku teks terdapat KI dan KD berdasarkan dokumen KI dan KD Kurikulum 2013. Uraian konten pada buku teks tersebut cenderung singakat, sehingga siswa harus lebih aktif untuk mencari informasi tambahan dan peran guru sangat diperlukan saat kondisi seperti ini sebagai pendidik. Sehigga buku-buku teks kimia yang digunakan oleh guru dan siswa pada pembelajaran berpeluang menimbulkan terjadinya miskonsepsi (Suja \& Retug, 2013a,b). Faktor internal adalah faktor yang berasal dari dalam diri siswa, yaitu rendahnya pemahaman siswa terhadap materi ikatan ion dan ikatan kovalen. Hal tersebut tampak pada saat mereka menggambarkan proses terbentuknya ikatan antar atom dalam molekul senyawa HCN. Kedua, terjadi karena ketidakpahaman siswa tentang level submikroskopis kimia. Sebagai contoh, dalam menjelaskan sifat fisika kristal ionik yaitu keras, tetapi rapuh. Siswa sebagian besar menjelaskan bahwa sifat rapuh dari kristal ionik disebabkan kristal ionik dapat menghantarkan listrik dalam bentuk larutan. Secara ilmiah, Kristal ionik bersfat rapuh karena saat kisi kristalnya digeser akan terjadi tolakmenolak antar ion-ion yang bermuatan sama.

\section{SIMPULAN DAN SARAN}

Berdasarkan hasil penelitian diatas, simpulan dalam penelitian ini adalah sebagai berikut, profil model mental alternatif siswa kelas X SMA Laboratorium Undiksha Singaraja tentang ikatan ion dan ikatan kovalen sebanyak $38,89 \%$. Model mental alternatif tersebut terdiri atas $34 \%$ model mental benar sebagian dan 4,89\% model mental miskonsepsi khusus dan faktor-faktor penyebab model mental alternatif, meliputi faktor eksternal yaitu buku teks kimia yang digunakan oleh guru dan siswa. Faktor internal rendahnya pemahaman siswa terhadap materi ikatan ion dan ikatan kovalen dan ketidakpahaman siswa tentang level submikroskopis kimia. Berdasarkan hasil hasil penelitian dan pembahasan di atas dapat disampaikan saran sebagai berikut, guru kimia di SMA perlu menerapkan metode dan strategi pembelajaran yang tepat dalam proses pembelajaran ilmu kimia dan buku ajar kimia yang digunakan hendaknya mencakup ketiga level kimia, yaitu level makroskopis, level submikroskopis, dan level simbolik.

\section{DAFTAR RUJUKAN}

Arikunto, S. 2012. Dasar-Dasar Evaluasi Pendidikan Edisi 2. Jakarta: Bumi Aksara.

Chang, R. 2005. Kimia Dasar KonsepKonsep Inti Edisi Ketiga Jilid I. Jakarta: Erlangga.

Coll, R. K., 2008. Chemistry Learners' Prefered Mental Models for Chemical Bonding. Journal of Turkish Science Education, 5(1): 22 - 47.

Creswell, John, W. 2010 Research Desain Qualitative Quantitative, and Mixed Methods Approaches. Lincolin: University of Nerbraska. 
Devetak, I., E.D Lorber, Jurisevic. M., \& Glazar, S.A. 2009. Comparing Slovenian Year 8 and Year 9 Elementary School Pupils' Knowledge of Electrolyte Chemistry and Their Intrinsic Motivation. Journal Chemistry Education Research and Practice.Volume 10 (hlm. 281-290).

Halim, N. D. A., Mohamad, B. A., Noraffandy, Y., Mohd, N. H. M. S. 2012. Mental Model in Learning Chemical Bonding: A Preliminary Study. Journal of Procedia - Social and Behavioral Sciences 00 (2013) 000-000.

Jansoon, N., Coll, R. K., \& Somsook, E. 2009. Understanding Mental Models of Dilution in Thai Students. International Journal of Environmental \& Science Education, 4(2), 147-168. Tersedia pada http://files.eric.ed.gov

Kunde, J.W., Suja, I W, \& Redhana I W. 2018. Profil Model Mental Siswa Kelas X SMA Laboratorium Undiksha Singaraja tentang Bahan Kajian Stokiometri. Singaraja: Universitas Pendidikan Ganesha. Tersedia pada http://ejournal.undiksha.ac.id

Park, E. J. 2006. Student Perception and Conceptual Development as lirepresented By Student Mental Models of Atomic Structure. Disertasi tidak dipublikasikan. Colombus: The Ohio State University.

Riyastini, I G. A. P. Y. 2015. Analisis Pemahaman Kimia Siswa pada Topik Stoikiometri di SMA Laboratorium Undiksha Singaraja. Skripsi tidak dipublikasikan. Singaraja: Undiksha.

Sendur, G., Toprak, M., \& Pekmez, E.S. 2010. Analyzing of Students' Misconceptions about Chemical Equilibrium. Paper on International Conference on New Trends in Education and Their Implications. Antalya- Turkey. Tersedia pada http://conference.pixelonline.net.

Sucitra, I. G. N. B. 2016. Pofil Model Mental Siswa tentang Korelasi Struktur Molekul terhadap Sifat Senyawa Organik. Skripsi tidak dipublikasikan. Singaraja: Undiksha

Sugiyono. 2014. Metode Penelitian Pendidikan Pendekatan Kuantitatif, Kualitatif dan R \& D. Badung: Alfabeta.

Suja, I W, \& Retug, N., 2013a. Profil Konsepsi Kimia Siswa Kelas XI di Kota Singaraja. Prosiding Senari (Seminar Nasional Riset Inovatif) Lembaga Penelitian UNDIKSHA ke1 ISSN 23391553, (hlm. 172-179). Tersedia pada

Suja, I W. 2015. Model Mental Mahasiswa Calon Guru Kimia dalam Memahami Bahan Kajian Stereokimia. Jurnal Pendidikan Indonesia, 4(2), 625-638.

Sunyono, Leny, Y., Muslimin, I. 2015. Mental Models of Students on Stoichiometry Concept in Learning by Method Based on Multiple Representation. Journal of New Horizons in Education. Volume 26 (hlm. 104-125).

Wang, Ch. Y. 2007. The Role of Mental-Modeling Ability, Content Knowledge, and Mental Models in General Chemistry Students' Understanding about Molecular Polarity. Columbia: University of Missouri. Tersedia pada http://mospace.umsystem. Edu

Yoni, A. A. I. S., Suja, I W, \& Karyasa, I W. 2017. Profil Model Mental Siswa SMA Kelas X tentang Konsep-Konsep Dasar Kimia pada Kurikulum Sains SMP. Singaraja: Universitas Pendidikan Ganesha. Tersedia Pada http://ejournal.undiksha.ac.id 